\title{
CORPO ESCANDALOSO: O CINISMO EM PINA BAUSCH
}

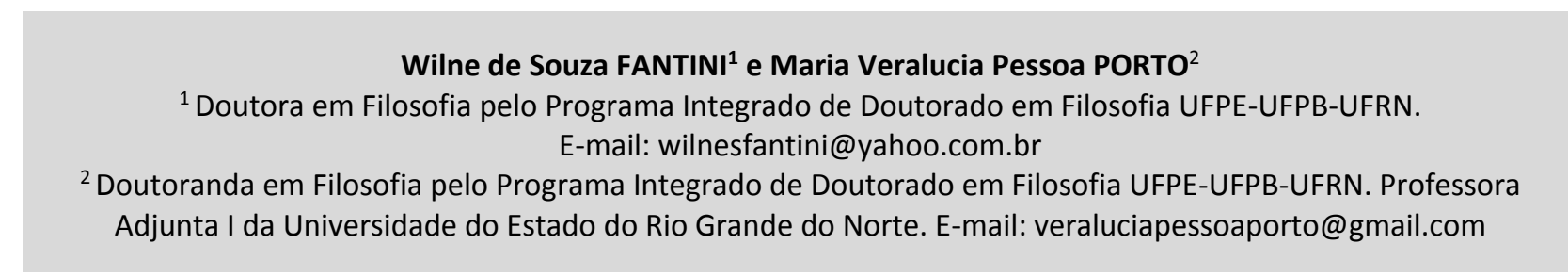

Artigo submetido em maio/2015 e aceito em maio/2015

DOI: 10.15628/dialektike.2015.3022

\section{RESUMO}

No presente artigo fizemos uma abordagem sobre os corpos dos bailarinos-atores do Wuppertal Tanztheater da coreógrafa alemã Pina Bausch ao mostrá-los como uma manifestação, na dança-teatro contemporânea, do cinismo antigo analisado pelo filósofo francês Michel Foucault. No intuito de desenvolvermos nossas reflexões, realizamos alguns recortes históricos tendo em vista tanto o respeito a cada positividade histórica e suas singularidades quanto a impossibilidade de abarcar a totalidade sobre o tema. Um desses recortes, diz respeito a alguns elementos que ajudam a compreender o corpo do ponto de vista do cinismo na Grécia Antiga. Como não foi nosso escopo abordar as "manifestações cínicas" de um modo geral, elegemos a perspectiva de Diógenes, o cínico, para embasarmos nossas análises acerca das relações de poder e de resistência presentes nos corpos daquela época. O segundo recorte, considera, dentro do arcabouço da história da dança, a dança-teatro de Pina Bausch. Em Bausch o corpo assume uma reconstrução, um redimensionamento que se aproxima das reapropriações do corpo segundo a perspectiva cínica ressignificada pela abordagem foucaultiana.

PALAVRAS-CHAVE: Corpo; cinismo; Michel Foucault; Pina Bausch.

\section{SCANDALOUS BODY : THE CYNISM IN PINA BAUSCH}

\begin{abstract}
In this paper it was done an approach on the bodies of Wuppertal Tanztheater dancers-actors of the German choreographer Pina Bauch, showing them as manifestation, in contemporain dance-theatre, of Cynism analized by the French philosopher Michel Foucault. In order to develop our reflections, we made some historical clippings, in view of as much respect at each historical positivity and its singularities as the impossibility to encompass the entire theme. One of these clippings, regarding some elements that helps to understant the body in the perspective of cynism in
\end{abstract}

Ancien Greece. As it was not our scope to report the "cynical manifestations" in general, we elected the prospect of Diogenes, the cynic, to base our analyzis concerning the relations of power and resistence present in the bodies of that period. The second clippings, considers, withing the framework of the history of dance, Pina Bausch's dance-theater. With Bausch the body assumes a reconstruction, a resize approaching the body reappropriations according to the cynical perspective resignified by Foucault's approach.

KEYWORDS: Body; cynism; Michel Foucault; Pina Bausch. 


\section{INTRODUÇÃO}

No presente artigo faremos uma aproximação entre as reflexões foucaultianas sobre o corpo cínico e os corpos dos bailarinos-atores do Wuppertal Tanztheater de Pina Bausch ao mostrá-los como uma manifestação, na dança-teatro contemporânea, desse cinismo antigo mencionado por Foucault. Tal aproximação deve-se ao fato de o trabalho de Bausch ir de encontro a uma tradição ocidental que diz respeito à complexa trama estética que envolve os corpos na dança. Por oposição a uma esteticização acadêmica, clássica do corpo, em Bausch o corpo assume outra forma de apresentação, uma reconstrução, um redimensionamento que se aproxima das reapropriações do corpo segundo a perspectiva cínica ressignificada pela abordagem foucaultiana.

O cinismo é considerado por Foucault como um ato de resistência à visão imposta pela filosofia clássica em seus ensinamentos, discursos abstratos e proposituras sobre uma verdade universalizada presente em todas as coisas, aí incluído o corpo ${ }^{1}$. Nesse sentido, a atitude cínica permite ultrapassar a visão tradicional de homem e o filósofo francês vai se servir dos elementos presentes nesse referencial para tratar de questões como a crítica ao saber clássico, a resistência às formas de dominação, a liberdade na construção da existência.

Embora não muito óbvio, está presente na atitude cínica uma relação entre teoria e prática que envolve estética, ética e política. O cinismo não recorre a livros, antes se baseia na existência, o que nos possibilita ver que em toda relação, principalmente naquelas que envolvem os corpos subsiste e persiste uma relação de poder e de força. Essa relação, quando perscrutada sob a forma do movimento apresenta alguns aspectos que são muito valorizados por Foucault, como a expressão de uma forma de liberdade e, ademais, uma verdade franca e espontânea em uma perspectiva parresiástica.

Diógenes foi o representante mais radical dessa concepção de corpo cínico, aquele que proclamou a liberdade de palavra, a fala franca, aquele que diz o que pensa a todos sem nenhuma discriminação seja ao homem comum, seja ao mais famoso dos filósofos, seja ao maior dos monarcas. Desse modo, ele nos apresenta a indissociabilidade entre a liberdade de palavras e a liberdade de ações, entre o trâmite livre das palavras e o movimento livre dos corpos. Contra a sisudez e a rigidez do pensamento lógico, Diógenes e os cínicos valorizavam o lúdico: "Ao contrário de seus aparentados na sabedoria, os cínicos amam a festa e aquilo que ela apresenta nela mesma, a potência da alegria ou da improvisação [...]" (ONFRAY, 1990, p. 63).

Assim como outras filosofias do período antropológico e helenístico que se puseram e se opuseram contra a vontade escolar expressa na Academia e no Liceu, o cinismo representou e ainda representa um desafio para a filosofia. A proposta cínica preconiza a liberdade, um retorno à natureza uma frugalidade de vida mais condizente com a existência humana. Diógenes foi o primeiro a levar a sério esse aspecto ético e estético propugnado pelo cinismo:

[...] percorria as ruas vestido com tribôn (manto grosseiro), carregando um alforje que continha tudo que era seu, descalço, com os cabelos longos e barbudo, não hesitando em praticar atos "indiferentes", como comer em praça pública - o que aparentemente chocava seus contemporâneos [...]. Essa prática da adiaphoria, que o leva a transgredir tabus, é acompanhada por um modo de vida baseado no retorno à natureza e na fuga às convenções da vida civilizada; é preciso alimentar-

\footnotetext{
${ }^{1}$ Como nos diz Michel Onfray (2008, p. 130) em sua Contra-história da filosofia: “[...] a luta é contra o idealismo de Platão [...]".
} 
se frugalmente, deitar-se em chão duro, só buscar os prazeres naturais como a fruição das estações [...]. (GOULET-CAZÉ, 2001, p. 294)

Os cínicos, como podemos ver, vão se contrapor a um tipo de ordem vigente, a um tipo específico de estrutura que anula o aspecto livre e simples da existência. Assim, contra a rigidez das formas, o cinismo preconiza a alegria e a busca de expressões mais naturais para dar conta da vida. Podemos aludir, em nossa relação do cinismo com a dança, que essa atitude, de uma forma ou de outra, pode ser encontrada nos corpos dançantes de cada época. Assim, nomes como JeanGeorges Noverre, Marie Taglioni, Isadora Duncan, Vaslav Nijinski, Mary Wigman e Martha Graham, por exemplo, teriam transgredido os cânones vigentes e contribuído com inovações no âmbito do balé.

Portanto, a despeito de possíveis paradoxos e considerados dentro de seus limites históricos, o corpo do bailarino de corte, do bailarino clássico, do romântico, do moderno e do contemporâneo representa a expressão de um desejo de liberdade, de ultrapassar os limites do corpo e mesmo os limites estritos estabelecidos pelos status quo estético vigente, pela técnica aceita e reproduzida de forma canônica. Por conseguinte, mesmo em face de estruturas e exigências técnicas, o tempo todo, seja no momento de uma improvisação, seja na hora de executar uma coreografia ou mesmo na hora de fazer uma aula, o bailarino revela sua irreverência, sua subversão, sua infâmia e nos permite vislumbrar seu corpo sob a determinação da concepção cínica da existência, do espetáculo, do movimento. Nesse sentido, essa transgressão não é, de fato, exclusividade da perspectiva bauschiana sobre o corpo. Todavia, identificamos em nossa investigação a existência de coincidências em relação ao corpo entre a transgressão cínica e a proposta inovadora de Bausch. É, então, nesta perspectiva que temos o objeto da nossa abordagem, o corpo escandaloso: o cinismo em Pina Bausch.

Contudo, não será nosso intuito abordar as "manifestações cínicas" em todos esses momentos históricos. Mesmo porque, baseando-nos no pensamento de Foucault quer quanto aos fundamentos, mas também quanto às práticas, devemos, a exemplo do pensador francês, respeitar cada positividade histórica e suas singularidades subjacentes. Portanto, nesse breve itinerário cabe-nos inicialmente considerar alguns elementos básicos do movimento cínico, a saber, a compreensão do corpo na perspectiva cínica, a fim de desvelar elementos que venham a ter relação com a dança de Bausch e que nos possibilite compreender a singularidade do trabalho da coreógrafa alemã.

A perspectiva abordada em nossa investigação tem como pressuposto a referência feita por Foucault entre o cinismo e a arte, quando este afirmou que em toda forma de arte subsiste uma espécie permanente de cinismo. Assim sendo, tendo por base essa abordagem foucaultiana, fizemos um recorte pontual na história da dança e destacamos os corpos contemporâneos dos bailarinos-atores de Pina Bausch, buscando estabelecer suas relações com a interpretação foucaultiana do corpo cínico na Grécia Antiga.

\section{A SABEDORIA CÍNICA DO CORPO DESNUDADO DAS “VESTES" DA FILOSOFIA ESSENCIALISTA}

O cinismo tem suas origens em Atenas. Seu fundador, Antístenes, viveu no momento em que se davam os embates entre os sofistas e Sócrates. Enquanto os primeiros propugnavam o relativismo dos valores, das crenças, da verdade, Sócrates preconizava a necessidade de um 
critério válido, universal e permanente para avaliar todas as coisas. Conforme Christoph Eucken (2003, p. 144) em Antístenes: a independência espiritual do indivíduo, "[d]epois de Platão, Antístenes é o discípulo mais importante de Sócrates", o resultado desse encontro vai desembocar em duas perspectivas diferentes sobre a existência, a vida, o corpo. De um lado a teoria que vai se consagrar como predominante, a de Platão, baseada nos ensinamentos de Sócrates sobre a alma. Essa vai considerar a alma como a sede do entendimento e afirmar sua prevalência sobre o corpo, sobre as sensações, sobre os instintos.

A filosofia de Platão, cujo conceito fundamental é a ideia, vai ser chamada de idealista e vai se caracterizar, em sua recepção mais geral, por uma dissociação com a vida prática. Nesse tipo de filosofia será comum encontrar como guia para as ações humanas, princípios transcendentes, conceitos universais, considerações ideais alheias ao aspecto particular e mesmo singular da existência cotidiana, porque ausentes das "misturas" do mundo corpóreo tendo sido forjados por meio de abstrações universalizantes, em verdades fundadas ao nível das formas, sem nenhum conteúdo ou vínculo com as experiências reais e práticas.

$O$ resultado de uma perspectiva como essa consiste em considerar o ser humano como portador de uma espécie de alma universal que é a síntese da existência humana. Essa alma é a sede da razão, se constituindo como o princípio que deve ordenar e conduzir o corpo. Instaura-se então, o monopólio da alma, que passa a ser a parte mais relevante do homem. $\mathrm{O}$ corpo assume o papel de cárcere do qual a alma anseia se libertar. Nesse sentido, o ser humano se encontra destituído de uma singularidade corpórea. O corpo se universaliza enquanto prisão e, paradoxalmente, enquanto tal, encerra a alma, sendo apreendido, desde então, em uma universalidade indiferenciada, inespecífica. Sua dotação de sentido vem de dentro. A alma considerada como única unidade de valor da existência - vive e vence o corpo-cárcere no qual se encontra encerrada. O corpo, por sua vez, só encontra seu lugar enquanto "caverna", enquanto contraposto à alma.

Assim, desprovido em sua especificidade, o corpo se encontra inerte, sendo revestido e animado por conceitos, leis, normas, regras que o ignoram. Daí a necessidade do corpo em ser conduzido a um mundo ordenado, planificado e ideal. Essa concepção de mundo impede o indivíduo de objetivar o mínimo de verdade em si próprio, em sua corporeidade, na sua própria vida e em suas ações.

Tomando por base essa forma de especulação filosófica, nascida do confronto entre Sócrates e os sofistas, o cinismo pode ser considerado, por oposição a ela, como uma segunda perspectiva, como um ato de resistência a um tipo de filosofia que se impôs e que, ao longo dos tempos, se cristalizou por meio de seus ensinamentos e de seus discursos. Nesse sentido, as formas de pensamento, ação e de construção que se imponham e se oponham ao ideal grego clássico, cujas figuras centrais serão Sócrates e Platão, vão estar, de certo modo, na esteira do movimento cínico.

Uma vez que a filosofia de Platão preconizava que o modelo para todas as coisas eram as ideias, as essências, sua filosofia pode ser considerada como essencialista. Desse modo, o próprio corpo foi revestido de uma essência. Travestido de

cárcere, coube ao corpo, quando muito, participar naquilo que lhe é próprio das tentativas de definir o homem. Assim, em função das partes e características do corpo humano, dizia Diógenes, Platão define o homem como bípede, por causa de seus dois pés, e sem plumas, por causa da higidez de sua pele em relação, digase de passagem, às partes dos corpos de outros animais. Mas esse tipo de definição essencialista não satisfaz a Diógenes. Assim, ele sai em meio às feiras 
segurando pelo pescoço uma galinha depenada apresentando-a aos transeuntes como o "homem de Platão" (ONFRAY, 2008, p. 132).

Essa busca pelo homem ideal nos é apresentada em outra anedota atribuída ao pensador cínico segundo à qual ele saia pelas feiras com uma lanterna acesa em plena luz do dia à procura do homem verdadeiro que seria, supostamente, aquele que fora preconizado pela filosofia essencialista de Platão:

De fato, Diógenes não procura tanto um homem em especial, tal como poderia encontrar ou reconhecer na multidão, mas busca ironicamente o homem de Platão, a humanidade quintessenciada - pois, é claro, não se encontra ideia mais do que forma inteligível, dar de frente com um conceito é uma possibilidade tão pequena quanto a de encontrar um hipogrifo ou um centauro! Tampouco existe um Homem digno desse nome por suas qualidades desenvolvidas, trabalhadas e sublimadas... O ideal não existe, nunca o encontramos - daí a busca infrutífera com a lanterna. (ONFRAY, 2008, p. 131-132)

Por conseguinte, da inadequada compreensão do que venha a ser o homem, principalmente em meio a discursos com pretensões de apreensões universais, de identidades morais, de verdades ordenadas e, por outro lado, práxis desenraizadas, têm-se, nos cínicos, o que aqui intitulamos de o "desnudamento do corpo das 'vestes' da filosofia essencialista". E, Diógenes, o filósofo que andava nu, se nos apresenta como o "modelo ideal" desse movimento de desnudamento, uma vez que ele, por seu viver frugal, prescindia de roupas físicas e conceituais.

Diógenes vivia uma prática pedagógica que, ao invés de revestir o mundo de essências, propugnava o viver em meio à praça tentando ensinar os homens, buscando, ademais, afastá-los de falsas concepções:

[...] É ele quem põe a descoberto as falsas evidências e derruba todas as máscaras. Pedagogo do gênero humano e médico das almas, o filósofo da lanterna [...] opõe o sábio à multidão de escravos, ou seja, os homens que perseguem falsos valores. Para mostrar a seus contemporâneos o caminho reto, com seu espírito crítico exacerbado não hesita em usar a invectiva com objetivo pedagógico, que pode ir da zombaria pura e simples à grosseria provocante. Por outro lado, abre os olhos de seu interlocutor fazendo-o descobrir que tudo o que parece pacífico, em especial as convenções, deve ser questionado e substituído por outros valores [...]. (GOULET-CAZÉ, 2001, p. 294).

Desse modo, com o cinismo, aparecem novas relações de poder que ressoam nos indivíduos através de novos estilos de vida. Claro que essas lições de Diógenes nem sempre foram aceitas de bom grado. Ele se considerava como um médico, seu objetivo era cuidar de seus conterrâneos, mas nem todos queriam ouvir as lições de sua 69ceita69peia. Entretanto, para aqueles que ouviram a voz do filósofo cínico, o corpo que fora desnudo de uma perspectiva conceitual deve agora usar vestimentas mais apropriadas, visando a si mesmo em sua singularidade. Deve o indivíduo, por exemplo, comer apenas os alimentos necessários à nutrição e vestir um simples manto, desprezando os excessos e as vaidades.

Contudo, vale salientar que, a ociosidade, a opacidade, a letargia ou, tantos outros adjetivos que definam uma atitude de espera, isto é, aquela atitude que se resigna na espera de que as coisas aconteçam como que por acaso na vida, bem como, o louvor à falta de condições mínimas para sobreviver, não podem ser consideradas como dignas da atitude cínica. O mínimo de verdade, 
de luta, de resistência é o que permite estabelecer, a partir da vida cínica, uma relação que não é mais da ordem da ornamentação, da ordem da imitação, mas que é da ordem do desnudamento, e do voltar a si próprio, numa redução violenta das condições próprias à existência em suas estruturas mais elementares.

Há que se destacar ainda que, apesar de termos traçado certa identidade e homogeneidade nos discursos e práticas cínicas, fontes antigas sobre o movimento apresentam-no segundo uma abordagem paradoxal ou mesmo segmentada, dando conta da existência de um cinismo teórico e de um cinismo prático. O teórico teria como fundador Antístenes e, o prático, Diógenes, representado comumente como um radicalizador do cinismo. Em Vida e doutrinas dos filósofos ilustres, Diógenes Laêrtius narra como se teria dado o encontro entre os filósofos Antístenes e Diógenes, o cínico. A forma e condição do encontro, conforme nos é narrada, assinala o quanto o cinismo se constitui como o locus da irrupção de formas de vida que, na cultura e nos modos de existência formalizada, ainda não possui possibilidade de expressão. A vida revestida por conceitos, velada, implica na necessidade de um desnudamento, numa referência explícita às reverências contra as quais o corpo precisa, em algum momento, se insurgir.

Conforme Laêrtius, Diógenes, o cínico, exilado de Sinope, chegando a Atenas encontrou-se com Antístenes. Este, não querendo receber a ninguém como aluno, despediu-o. Formalmente o desejo de Antístenes deveria ser respeitado e o discípulo rejeitado faria por bem, segundo os "bons costumes", dar adeus às suas pretensões e, mesmo por orgulho, ir embora. Diógenes, por sua vez, perseverando assiduamente na assistência aos ensinamentos do mestre cínico, conseguiu convencê-lo aceitá-lo.

Ainda, de acordo com variações da mesma narrativa, certa vez Antístenes ergueu o bastão contra Diógenes, para afugentá-lo, dada a sua insistência, após não ter sido aceito, em estar ao lado do mestre. O discípulo insistente, por sua vez, ao invés de ir embora ofereceu a cabeça às bordoadas, dizendo: "Golpeia, pois não acharás madeira tão dura que possa fazer-me desistir de conseguir que me digas alguma coisa, como me pareces que é teu dever" (LAÊRTIUS, 1988, p. 159). A partir daí, tornou-se Diógenes ouvinte de Antístenes e, como exilado, como alguém sem posses, dedicou-se a um moderado estilo de vida.

A insistência de Diógenes tem um aspecto propedêutico: ela apresenta uma verdade que se nos aparece associada ao dever de Antístenes. Entretanto, não se trata da verdade como realização plena, como um ressoar unívoco, antes ela se apresenta como um elemento provocador a nos indicar as batalhas e as lutas que devemos encetar para encontrar esse homem perdido em meio aos costumes e às convenções. Desse modo, em vez de travestir o homem de mais conceitos, é preciso, acima de tudo, desnudá-lo.

Dessa forma, tem-se que o aspecto mais relevante desse desnudamento do corpo das "vestes" da filosofia conceitual está na célebre busca de Diógenes quando mencionava: "procuro o homem". Essa busca se tratava de uma evidente e provocadora ironia, pois ele queria evidenciar de maneira imagética a sua suspeita acerca do ideal de homem que se dizia presente em sua época. Assim, contra esse ideal de homem revestido e travestido de uma essência, Diógenes contrapunha o homem fincado na existência, acima de todas as convenções, um ser real e que, na sua existência, é superior a todas as regras impostas pela sociedade, alguém além do capricho do destino e da fortuna, o homem que reencontra sua "natureza" genuína, e vive em conformidade com essa "natureza".

Somente um homem dessa estatura poderia ser feliz. Entretanto, para Diógenes, tal homem se encontrava oculto, encoberto, velado. Para o filósofo cínico nem mesmo a luz solar, aquela mais radiante e clara estava sendo suficiente para desvelar o verdadeiro do homem. Tudo que se 
apresentava aos seus sentidos consistia em uma aparência falsa daí, sarcasticamente, ele se utilizava da lanterna como algo que poderia vir a auxiliar no encontro com esse homem que escapava mesmo à clareza do sol em sua grandeza estelar.

A imagem proposta por Diógenes nos remete às falhas tanto de uma concepção idealista de homem quanto da ordem da natureza considerada de forma harmoniosa. Tais concepções dos seres e dos valores (o bem, o belo) não ocupam mais o espaço único e absoluto da compreensão do real. Surgem, então, com o cinismo, espaços outros que, ao invés de confrontarem o homem com a idealidade, possibilitam a exposição da vida do ser humano ao olhar do outro, possibilitando, assim, uma abertura a uma nova forma de inserir-se na realidade. A exemplo do que queremos indicar, o próprio Diógenes dizia que na cultura grega os homens, geralmente, competiam cavando fossos ou esmurrando-se, entretanto, ninguém competia tendo em vista tornar-se moralmente excelente.

Nesse sentido, Diógenes, em sua crítica à sociedade, percebe e denuncia as contradições de uma compreensão e uma prática acerca do humano que são, igualmente, abstratas: o que se pretende que seja o homem nada mais é do que considerações que não transformam o real, ao contrário, o ignoram e, assim, o desfiguram. O resultado é uma ideia abstrata de homem que não se efetiva, que não se constitui em função da simples noção de que um ideal é suficiente, não havendo nenhuma preocupação em praticá-lo. Assim, Diógenes:

Admirava-se vendo os críticos estudarem os males de Odisseus apesar de
ignorarem seus próprios males; ou os músicos afinarem as cordas da lira sem
cuidarem de obter a harmonia de sua alma; ou os matemáticos perscrutarem o
sol e a lua, mas ignorarem a realidade sob seus próprios olhos; ou os oradores
cansarem-se de falar de justiça, mas não a praticarem; ou os avarentos
esbravejarem contra o dinheiro, enquanto na realidade o amam exageradamente.
Diôgenes [sic] condenava as pessoas que, embora louvando os justos por estarem
acima das riquezas, invejavam os homens muito ricos. Revoltavam-no os
sacrifícios aos deuses pela saúde, porque durante os próprios sacrifícios as
pessoas se banqueteavam em detrimento da saúde, e se admirava quando os
escravos, embora vendo seus senhores comendo desbragadamente, nada
subtraíam das iguarias. (LAÊRTIUS, 1988, p. 159)

Segundo o texto de Laêrtius, o filósofo cínico capta uma série de oposições presentes no modelo essencialista. Ele percebe, a exemplo da citação acima, o jogo de forças existente entre senhores e servos, muito embora não aceitasse tal tipo de moralidade. Tal jogo de forças se expressa na quietude do servo que não ousava usufruir das diversas iguarias presentes nos banquetes dos senhores, muito embora, em função da quantidade, tal usufruto por parte dos servos não representasse prejuízo algum ao banquete.

Contrário a esse tipo paradoxal de existência, Diógenes apresenta uma educação voltada para o exercício de determinadas práticas que possibilitem o cuidado de si. Alguns exemplos de práticas, por ele, estão preservados em alguns textos de história da filosofia. Entre essas práticas encontramos o hipismo ou o ato de cavalgar, pois, para o cínico, trata-se de uma experiência singular que apresenta um duplo movimento: o mover no caminho trilhado e o mover de cima para baixo, bem como o seu contrário, impulsionado pela força do trote do animal. Além do hipismo, há também a prática do arco e flecha que exige para sua execução a um só tempo: mira, força e velocidade. Outra prática, encontrada nessa época, é o jogo de dardos com suas estratégias, movimento, velocidade, tática, dentre outras. Hipismo, arco e flecha, dardo são 
exemplos de práticas e exercícios para enfrentamento das intempéries da vida que em si não é harmoniosa e apaziguadora, mas repleta de competição e de luta contínua.

Laêrtius, a partir de Êubulos em sua obra intitulada Diôgenes à venda, apresenta-nos outros aspectos interessantes sobre Diógenes que ratificam sua prática do cuidado de si enquanto modelo de vida:

[...] educou os filhos de Xeníades de tal maneira que, depois de outras disciplinas, Ihes ensinou a cavalgar, a atirar com o arco, a lançar pedras e a arremessar dardos. Mais tarde, na escola de luta não permitiu ao mestre dar-lhes uma educação atlética completa, mas apenas exercitá-los até adquirirem a cor avermelhada e as condições normais de saúde. Os meninos sabiam de cor muitos trechos de poetas e prosadores, além de obras do próprio Diôgenes, [sic] e ele os treinava todo o tempo para terem boa memória. Em casa ensinava-os a cuidar de si mesmos, a nutrir-se com alimentos simples e a beber apenas água, cortava-lhes os cabelos bem curtos, privando-os de quaisquer ornamentos, educando-os para andarem sem túnica, descalços, silenciosos, e para cuidarem somente de si mesmos nas ruas; além disso levava-os algumas vezes a caçar. Os meninos, por seu turno, tinham grande consideração por Diôgenes, [sic] e intercediam por ele junto a seus pais. (LAÊRTIUS, 1988, p. 160).

O mesmo Êubulos indica que Diógenes envelheceu junto a Xeníades, e quando aquele morreu, foi sepultado pelos filhos deste. Acerca disso, uma curiosidade ainda pode ser observada: quando Xeníades perguntou à Diógenes como este queria ser enterrado após sua morte, sua resposta foi: "com o rosto para baixo". E, quando the perguntaram a razão ele respondeu o seguinte: "porque [...] dentro de pouco tempo o que está em baixo passará a estar por cima", querendo dizer com essa resposta que os macedônios iriam dominar a Grécia e que, assim, de humildes que eram tornar-se-iam poderosos (LAÊRTIUS, 1988, p. 160).

Ainda nos é interessante relatar alguns outros aspectos do pensamento de Diógenes, de modo a não cair em armadilhas conceituais ou enveredar para uma espécie de "endeusamento ou heroísmo" das atitudes cínicas em relação à filosofia conceitual vigente. Desse modo, se faz necessário observar que, mais que "endeusamento ou heroísmo", toda a atitude cínica é, de fato, fruto da resistência ao ideal vigente, seja em que época for. Isso significa dizer, então, que essas ideias contêm elementos que, ao mesmo tempo em que irritaram Diógenes, o impulsionaram a uma forma de resistência:

[...] Quando Platão o chamou de cão ele replicou: 'É verdade, pois volto sempre a quem me vendeu.' A saída dos banhos públicos alguém lhe perguntou se havia muitos homens banhando-se, e sua resposta foi: 'Não'; perguntando-lhe outra pessoa se havia muita gente, a resposta foi: 'Sim'. Platão definira o homem como um animal bípede, sem asas, e recebeu aplausos; Diôgenes [sic] depenou um galo e o levou ao local das aulas, exclamando: 'Eis o homem de Platão!'. Em consequência desse incidente acrescentou-se à definição: 'tendo unhas chatas'. A alguém que lhe perguntou à que horas devia almoçar, sua resposta foi: 'Se fores rico, quando quiseres; se fores pobre, quando puderes.' (LAÊRTIUS, 1988, p. 162)

Assim, no que diz respeito à postura de Diógenes, dois aspectos ainda nos chamam a atenção. O primeiro, não muito óbvio, mas próprio da atitude cínica, é a de que toda relação é uma relação de poder e força que se encontra em movimento. Trata-se de uma força centrífuga e real 
perpassada por embates entre o que está posto e a resistência e a rejeição deste modelo em função de uma adesão aos valores associados à vida e ao corpo, às práticas de uma existência livre e ao cuidado de si. O segundo, mais claro e acentuado, associado ao primeiro, diz respeito à atitude parresiástica que consistia na liberdade de palavra, na fala franca. Diógenes, por exemplo, dizia o que pensava a todos sem nenhuma discriminação quer seja ao homem comum, seja ao mais famoso dos filósofos ou mesmo ao maior dos monarcas. Diógenes apresenta-nos, por conseguinte, como indissociável à liberdade de ações a liberdade de palavra.

Destarte, mesmo que os relatos da atitude cínica apresentem para alguns de nós hoje em dia o que chamaríamos de limite da imprudência ou de abuso, trata-se de uma liberdade de ação que pretende demonstrar que a mera convenção de certos usos e costumes nada mais é do que formas de enquadramento e de adestramento, daí a necessidade do desnudamento do corpo das vestes da filosofia essencialista de modo a deixar o indivíduo livre para traçar os seus próprios movimentos e, neles, definir sua própria existência, forma de pensar e de viver que se constitui como um desafio a ser considerado pelas mais variadas formas de expressão humana, como é o caso da dança-teatro de Pina Bausch, objeto de nossa investigação nesse artigo.

\section{O CORPO BAUSCHIANO E O CINISMO}

A dança-teatro alemã nasceu no início do século XX, entre os anos 20 e 30, a partir dos trabalhos de Rodolf von Laban (1879-1958), Mary Wigman (1886-1973) e Kurt Jooss (1901-1979). O propósito dessa nova expressão da dança foi retratar uma reflexão sobre a vida das pessoas do final do século XIX ao século XX: o individualismo, a solidão, a efemeridade, a objetificação dos corpos. Os alemães abandonaram as sapatilhas de ponta, as saias fofas chamadas de tutus, os pas de deux e os arabesques e buscaram "[...] uma arte nova, provocadora, que levava para o palco angústias, dores, impotências e raivas que passavam a quilômetros das harmonias [...] do [balé acadêmico]." (CALDEIRA, 2009, p. 26).

Na década de 70, a bailarina e coreógrafa alemã, Pina Bausch, inicia seu trabalho na cidade de Wuppertal quando assumiu, entre 1973-1974, a seção de dança-teatro. Pina Bausch visou transformar a dança acadêmica, incorporando-a e alterando-a ao usar, em suas coreografias, tanto gestos técnicos quanto cotidianos. Ademais, fundiu elementos da dança de salão, do circo, do teatro, da ópera, da pantomima e do cinema. Logo, os bailarinos não são apenas dançarinos, eles são bailarinos-atores, pois trabalham todos esses planos entrecruzados, gerando um campo muito mais amplo de possibilidades de encenação (FERNANDES, 2007; GIL, 2001). Desse modo, os bailarinos-atores do Wuppertal Tanztheater contam nas peças a história, de um modo geral, do gênero humano transcendendo ao dualismo e ao maniqueísmo.

A abordagem que Bausch dá à dança pode ser equiparada ao caminho trilhado pelos cínicos na sua luta conta as convenções oriundas da tradição filosófica que remonta à Platão. No cômputo geral dessa batalha, o essencialismo se mostrou mais adequado aos modos de constituição do real e vigora, ainda hoje, como o modelo vencedor que se espraia em todas as áreas da existência humana. Mas a via do cinismo persiste como uma forma constante de resistência a desafiar a filosofia essencialista encastelada em todos os campos da vida. Nesse sentido, a dança-teatro de Pina Bausch representa uma forma dessa luta e dessa resistência que segue a trilha aberta pelos cínicos. 
De acordo com o filósofo francês Michel Foucault (2011, p. 165), “[h]á em toda forma de arte uma espécie de permanente cinismo em relação a toda arte adquirida" porque "[...] a arte estabelece com a cultura, com as normas sociais, com os valores e os cânones estéticos uma relação polêmica de redução, de recusa e de agressão." (Ibid., p. 165).

Foi na Modernidade que, ainda segundo Foucault (2011, p. 164-5), a arte constituiu-se como veículo do cinismo, pois

[é] a ideia de que a própria arte, quer se trate da literatura, da pintura ou da música, deve estabelecer com o real uma relação que não é mais da ordem da ornamentação, da ordem da imitação, mas que é da ordem do desnudamento, do desmascaramento, da decapagem, da escavação, da redução violenta ao elementar da existência. Essa prática da arte como desnudamento e redução ao elementar da existência é algo que se assinala de uma maneira cada vez mais sensível a partir sem dúvida de meados do século XIX. A arte (Baudelaire, Flaubert, Manet) se constituiu como lugar de irrupção do debaixo, do embaixo, do que, na cultura, não tem direito, ou pelo menos não tem possibilidade de expressão.

Podemos afirmar que o corpo bauschiano trata-se de um corpo cínico, uma vez que Pina Bauch nos instigava ao desnudamento da experiência. Isso significa dizer que a coreógrafa alemã possuía o mesmo intuito dos cínicos no que diz respeito à liberação de todas as necessidades, de todas as frivolidades, de todas as superficialidades e de todos os desejos criados pelas convenções sociais. Os cínicos desdenhavam essas conveniências sociais e, um dos aspectos atribuídos ao cinismo, principalmente as representações de Diógenes, consistia em alterar ou mudar o valor da moeda. Ora, o que isso significava? Conforme Diógenes Laêrtius em Vidas e doutrinas dos filósofos ilustres, Diógenes (o cínico) era filho do banqueiro lquêsios. Ao seu pai fora confiado o dinheiro da cidade de Sinope. Iquêsius, aproveitou-se da função e adulterou a moeda.

[...] Eubulides, em seu livro sobre Diôgenes, afirma que o próprio Diôgenes agiu dessa maneira e foi forçado a deixar a terra natal com seu pai. Diôgenes, aliás, em sua obra Pôrdalos, confessa a adulteração da moeda. Dizem alguns autores que, tendo sido nomeado superintendente, deixou-se persuadir pelos operários, e foi a Delfos ou ao oráculo Delio na pátria de Apolo perguntar se deveria fazer aquilo a que desejavam induzi-lo. $O$ deus, deu-lhe permissão para alterar as instituições políticas, porém ele não entendeu e adulterou a moeda. Descoberto, segundo alguns autores, foi exilado, e segundo outros, deixou a cidade espontaneamente. Outros autores contam ainda que o pai Ihe confiou a cunhagem da moeda e que ele a adulterou; o pai foi preso e morreu; o próprio Diôgenes fugiu e foi a Delfos perguntar não se devia adulterar a moeda, e sim o que devia fazer para tornar-se mais famoso [...] (LAÊRTIUS, 1988, p. 157).

Acerca do significado da atitude do filósofo cínico, Foucault (2011) reconhece que se trata de uma questão de difícil entendimento, uma vez que esta possuía várias explanações. Contudo, dentre as muitas interpretações possíveis, uma que convém e que não pode ser desprezada é aquela segundo a qual a ação de Diógenes em mudar o valor da moeda se referia a uma alteração, a uma mudança do costume e da lei, pois sua atitude consistia em quebrar as regras, os hábitos e as convenções. Toda essa contestação, toda essa quebra das regras, dos hábitos e das convenções era, muitas vezes, mostrada nos corpos dos cínicos: 
Nenhum aspecto de sua[s] vida[s] será dissimulado atrás do pudor dos muros opacos. O cínico dorme e come nas ruas, faz amor e se masturba em praça pública. Sua existência é exposta sem nenhuma reserva, ao ponto em que a transparência se volta em impudor, da recusa às máscaras sociais e de pensamentos-passados se voltarem nas afirmações chocantes do corpo na sua nudez. (SFORZINI, 2014, p. 146-7).

Pina Bausch, na peça intitulada Arien, nos mostrou essa experiência de dança voltada para uma revelação do corpo nu e cru (como era o dos cínicos), despido da carapaça social e com suas complexidades e paradoxos. Por estarem desvelados, esses corpos voltam-se para si mesmos:

[...] cada um por si, os olhos fechados, com pequenos movimentos e pequenos gestos ainda muito estranhos e tateantes, plenos de prudência, gestos que parecem hermeticamente fechados ao mundo exterior, que ficam muito perto do corpo e fazem a dança sair de novo como possibilidade, os dançarinos começam pouco a pouco a tomar consciência deles mesmos e do espaço - a dançar, não se voltando para o exterior, mas ao contrário em direção a eles mesmos e em direção à percepção que permite ultrapassar a fronteira entre os corpos e o espaço. [...] Um barulho violento vindo do exterior põe fim ao silencioso e utópico reconhecimento da dança e de si mesmo. Os dançarinos abrem os olhos. Momento de medo, de incerteza, de esforço para recuperar as velhas certezas, para retomar distância face a face de si mesmo e se orientar neste espaço estranho que nomeamos de realidade. (HOGHE, 2010, p. 35-6).

Por conta desse comportamento escandaloso, os cínicos receberam um epíteto, o de "cão" e, o próprio nome do movimento pode ser atribuído a uma etimologia que remete ao termo grego kyon, que pode ser traduzido por cão, bem com ao fato de Antístenes ter ministrado seus ensinamentos no ginásio Cinosargo, cuja etimologia também está associada também a elementos caninos. Várias explicações tentam aclarar essa alcunha e o porquê dessa vida de cão que os cínicos levavam. Elas dizem respeito aos seguintes aspectos:

[p]rimeiro, a vida kynikós é uma vida de cão na medida em que não tem pudor, não tem vergonha, não tem respeito humano. É uma vida que faz em público e aos olhos de todos o que somente os cães e os animais ousam fazer, enquanto os homens geralmente escondem. A vida de cínico é uma vida de cão como vida impudica. Segundo, a vida cínica é uma vida de cão porque, como a dos cães, é indiferente. Indiferente a tudo o que pode acontecer, não se prende a nada, contenta-se com o que tem, não tem outras necessidades além das que pode satisfazer imediatamente. Terceiro, a vida dos cínicos é uma vida de cão, ela recebeu esse epíteto de kynikós porque é, de certo modo, uma vida que late, uma vida diacrítica (diakritikós), isto é, uma vida capaz de brigar, de latir contra os inimigos, que sabe distinguir os bons dos maus, os verdadeiros dos falsos, os amos dos inimigos. É nesse sentido que é uma vida diakritikós: vida de discernimento que sabe se pôr à prova, que sabe testar e que sabe distinguir. Enfim, quarto, a vida cínica é phylaktikós. É uma vida de cão de guarda, uma vida que sabe se dedicar para salvar os outros e proteger a vida dos amos. Vida de impudor, vida adiáphoros (indiferente), vida diakritikós (diacrítica, de distinção, de discriminação, vida de certo modo latida) e vida phylaktikós (vida de guarda, de cão de guarda). (FOUCAULT, 2011, p. 213-4). 
Podemos perceber que, no corpo que foi docilizado e adestrado pela disciplina, em algum momento pode insurrecionar aquilo que estava velado, pode insurgir esse lado cínico. Desse modo, para Sforzini (2014, p. 152),

[...] essa indocilidade nativa dos corpos permite compreender também, em Foucault, sua ontologia da verdade: a verdade existe apenas nos e pelos corpos, mas tomando corpo nos corpos, ela nunca se realiza plenamente e de maneira unívoca. Ela provoca batalhas, suscita disfarces.

É uma "[...] forma de existência como escândalo vivo da verdade [...]" (FOUCAULT, 2011, p. 158) em que o corpo é infame, contestador, violento, transgressor e resistente. Essa "[...] forma de existência como escândalo vivo da verdade [...]" era o princípio da não dissimulação cínica. 0 que isso quer dizer? Podemos depreender disso que os cínicos defendiam que a vida verdadeira, a vida reta se dava unicamente conforme e tão somente sob o domínio da lei natural. Logo, nenhuma lei, nenhuma regra, nenhum costume que foi convencionado pelo homem poderia ser tomado como marco a seguir. A vida cínica de impudor e de escândalo era uma bios alethès, ou seja, uma vida desvelada, sem dissimulações "[...] que não ocultava nada, uma vida capaz de não ter vergonha de nada." (Ibid., p. 214).

Quanto a esse aspecto, Foucault (2011) observa:

[...] uma vida não dissimulada é uma vida que não ocultaria nada do que não é ruim e não faria o mal pois não dissimula nada. [...] a não dissimulação, [...] deve ser a garantia e a caução de uma vida inteiramente boa, de uma vida que será boa porque inteiramente visível, pois bem, essa não dissimulação não deve fazer seus e aceitar os limites habituais, tradicionais do pudor, esses limites que os homens convencionaram e que imaginam indispensáveis. Ao contrário, ela deve fazer aparecer, sem limite e sem dissimulação, o que, no ser humano, é da ordem da natureza, logo da ordem do bem. Ou seja, a não dissimulação, longe de ser a retomada e a aceitação dessas regras de pudor tradicionais que fazem que as pessoas se envergonhem de fazer o mal diante das outras, deve ser a exposição da naturalidade do ser humano ante o olhar de todos. (FOUCAULT, 2011, p. 224)

Essa bios alethès, esse corpo não dissimulado dos cínicos, podem, por exemplo, ser vislumbrados em outros dois momentos de duas peças diferentes de Pina Bausch: um primeiro exemplo temos, na peça anteriormente citada, Arien, uma das bailarinas-atrizes, Ann Endicott, que ri continuamente ao se deparar com um grande hipopótamo que se encontra no palco. Devido à repetição - que é uma das características marcantes da dança-teatro de Pina Bausch -, sua risada torna-se exagerada e absurda, ao ponto de podermos interpretá-la como uma forma de debochar e de denunciar "[...] a falsidade da expressão na dança da vida e do palco." (FERNANDES, 2007, p. 58).

O segundo exemplo encontramos em 1980 - Ein Stück von Pina Bausch (1980 - Uma peça de Pina Bauch), na qual a bailarina-atriz Mechthild Grossmann

[...] usa um largo casaco de couro verde, na altura de uma mini-saia, uma meia de seda escura, um sapato de meio salto, com cabelos soltos constantemente caindo no rosto, e um dente da frente pintado de preto. [...] Enquanto caminha pelo palco com sua cabeça e ombros projetados para frente, suas pernas abertas para os lados, abre seus braços em fortes e rápidos cortes para os lados à frente e grita 
"fantástico" enfaticamente, e ri com exagero. Ela repete a palavra, a risada e o gestual várias vezes [...] (Ibid., p. 58).

Observamos que, nas cenas supracitadas, há sempre o elemento do exagero e do absurdo que se apresenta nos gestos repetidos, nos comportamentos e na apresentação estética das personagens (como Mechthild Grossmann, que se veste formalmente, mas possui um dente pintado de preto, parecendo que o mesmo estivesse faltando em sua boca). Essas cenas revelam a indocilidade dos corpos, o escândalo que, muitas vezes, está velado, a dissimulação da vida cotidiana.

A rebelião do corpo dançante apresentado nas peças da dança-teatro é uma espécie de "arqueologia dos modos de vida". Podemos interpretar essa interessante expressão, trazida por Inge Baxmann (2013) num texto intitulado Rebellion of the body, theatre of images and an inquiry into the sense of the senses, como uma tensão de forças que surge entre os modos convencionais dos estilos de vida ditados pelas normatizações dos comportamentos e o absurdo dos modos de vida manifestos nos movimentos e nos gestos repetidos insistentemente pelos bailarinos-atores do Wuppertal Tanztheater.

A mesma repetição de um modelo ideal de vida entre os gregos que o cinismo denuncia, de um modo geral, está presente na dança através de movimentos e práticas executados de forma sequenciada, reprisada e contínua. É também uma característica inerente ao âmbito disciplinar descrito por Foucault em suas análises sobre o poder e cuja finalidade é adestrar os corpos sob uma rígida vigilância hierárquica (nesse caso, do professor perante o bailarino) e, igualmente, "[...] promover o domínio do corpo humano, apagando suas 'falhas' e tornando-o tecnicamente e expressivamente 'perfeito'" (FERNANDES, 2007, p. 108).

A repetição é, ademais, uma característica marcante no procedimento criativo de Pina Bausch, e, embora essa repetição esteja inserida dentro do poder disciplinar e seja usada no Wuppertal Tanztheater, em alguns momentos, como parte tanto do treinamento dos bailarinos quanto nos ensaios e nas encenações, como disciplina normalizadora, controladora e adestradora dos gestos e dos corpos, ela também emerge, dentro das relações de poder pensadas por Foucault, como resistência, de onde se deriva o corpo escandaloso. A coreógrafa alemã faz uso da repetição disciplinadora como crítica tanto da tradição normalizadora do balé acadêmico quanto da sociedade disciplinar de um modo geral. Tal abordagem foi a mesma utilizada sobre o entendimento de homem por Diógenes, cuja sabedoria cínica desnuda o homem das vestes da filosofia essencialista.

Dessa forma, após legitimadas as coincidências antes prevista entre as concepções e vivências do que aqui denominamos "corpo desnudado" de Diógenes e "corpo escandaloso" de Bausch, podemos mencionar que a normatização e o controle dos corpos são fragmentados e repensados por meio do "escândalo da vida cínica" apresentado na emergência das estruturas cindidas e caóticas dos movimentos e gestos repetidos continuamente. Trata-se, portanto, do corpo contando sua própria história, já que, é no corpo que está registrada a história, é com ele que se pode descrevê-la. Os corpos dançantes dos bailarinos-atores são os veículos através dos quais Pina Bausch nos expõe as relações de poder, as coerções físicas impressas como marcas nos corpos, os condicionamentos, as convenções, as obediências e, também, a transgressão.

Tomando esses parâmetros das peças de Pina Bausch, asseveramos que há uma correlação entre a descrição que Foucault fez do corpo cínico e os comportamentos apresentados pelos bailarinos-atores do Wuppertal Tanztheater. Essa correspondência se dá pelo fato de tanto Pina Bausch quanto Foucault abordarem, respectivamente, as experiências da dança-teatro e do 
cinismo grego antigo como experiências de si, experiências do sujeito consigo mesmo, como uma atitude, como um ethos.

\section{CONSIDERAÇÕES FINAIS}

Segundo uma conhecida expressão, quando alguma coisa acontece no mundo real que se excede para além dos lugares comuns, dos catecismos vigentes e dos costumes diz-se, para explicar tal acontecimento deveras burlesco, que "a vida imita a arte". Nesse sentido, a arte consiste no lugar de todas as possibilidades, de todas as licenças poéticas, bem como de todas as licenciosidades.

Do encontro da dança-teatro de Pina Bausch com o pensamento cínico poderíamos, na contramão do ditado popular, dizer que a "arte imita a arte", significando com isso o encontro da "arte de viver dos cínicos", com o "viver a arte" em Pina Bausch. Tanto o corpo cínico quanto o corpo bauschiano são provocações a um modo clássico de ver e viver a vida. Ambos representam um desafio aos valores vigentes sendo cada um deles, ao seu próprio modo, exigente no que diz respeito ao que deve ser observado no corpo tendo em vista sua verdade maior e sua felicidade.

A subversão operada por Diógenes no câmbio uma vez que, de fato, ele adulterou a moeda corrente, nos dá conta da menor importância que ele dava à prescrição e ao cumprimento das leis, algo que ficava em um plano inferior à sua maneira de viver, ou seja, livre e fiel a si mesmo. Já em Bausch, a resistência é notada a partir dos movimentos e dos gestos executados por seus bailarinos-atores quando os criam e os relatam através das peças encenadas. $O$ corpo bauschiano - resistente e cínico - emerge a partir de uma releitura e de certo rompimento das amarras das convenções postas pelo balé acadêmico. Assim, há o surgimento de um espaço outro, um espaço de criação, que ao mesmo tempo em que dialoga e convive com os padrões vigentes, transgrideos. E, finalmente, em ambas as posturas, temos um vislumbre da intepretação foucaultiana sobre a resistência às convenções como uma forma do exercício das práticas de liberdade. Nesse sentido, o "viver como um cão" consiste numa arte que conduz à liberdade do corpo; um corpo capaz de denunciar as normatizações, as normalizações e os adestramentos a que somos impostos e, através daquilo que poderíamos considerar como escândalo, de revelar-nos a bios alethès, a vida não dissimulada.

\section{REFERÊNCIAS}

BAXMANN, Inge. Rebellion of the body, theatre of images and an inquiry into the sense of the senses. In: . CLIMENHAGA, Royd; et. al. The Pina Bausch sourcebook: the making of Tanztheater. London/New York: Routledge, 2013. p. 142-151.

CALDEIRA, Solange Pimentel. O lamento da Imperatriz: a linguagem em trânsito e o espaço urbano em Pina Bausch. São Paulo: Annablume: Belo Horizonte: Fapemig, 2009.

EUCKEN, Christoph. Antístenes: a independência espiritual do indivíduo. In.: ERLER, Michael; GRAESER, Andreas. Filósofos da antiguidade: dos primórdios ao período clássico - 1. São Leopoldo : Editora Unisinos, 2003.

FERNANDES, Ciane. Pina Bausch e o Wuppertal dança-teatro: repetição e transformação. 2. ed. São Paulo: Annablume, 2007. 
FOUCAULT, Michel. A coragem da verdade: o governo de si e dos outros II. Curso no Collège de France (1983-1984). São Paulo: Editora WMF Martins Fontes, 2011.

GIL, José. Movimento total - o corpo e a dança. Relógio Lisboa: D’água Editores, 2001.

GOULET-CAZÉ, Marie-Odile. Diógenes de Sinope. In: HUISMAN, Denis. Dicionário dos filósofos. São Paulo : Martins Fontes, 2001.

HOGHE, Raimund. Pina Bausch: histoires de théâtre dansé. Photos de Ulli Weiss. Paris: L’Arche, 2010.

LAÊRTIUS, Diôgenes. Vidas e doutrinas dos filósofos ilustres. Brasília : Editora Universidade de Brasília, 1988.

ONFRAY, Michel. Contra-história da filosofia: as sabedorias antigas, I. São Paulo : WMF Martins Fontes, 2008.

Cynismes. Paris : Éditions Grasset \& Fasquelle, 1990.

SFORZINI, Arianna. Michel Foucault : une pensée du corps. Paris : PUF, 2014. 